\title{
Improved Exploratory Behaviour and Body Weight in Mice following Chronic Diet Consumption of Mucuna flagellipes
}

\author{
Aduema Wadioni ${ }^{1, *}$, Amah Akuma Kalu ${ }^{2}$, Akunneh-Wariso Chris ${ }^{3}$
}

\section{Aduema Wadioni ${ }^{1, *}$, Amah Akuma ${ }^{2}$, Akunneh-Wariso Chris $^{3}$}

'Department of Medical Physiology, PAMO, University, of Medical Sciences, Port Harcourt, Rivers State, NIGERIA. ${ }^{2}$ Department of Medical Physiology, Imo State University, Imo State, NIGERIA.

${ }^{3}$ Department of Human Physiology, Abia State University, Uturu, Abia State, NIGERIA.

\section{Correspondence}

\section{Aduema Wadioni}

Department of Human Physiology, PAMO, University, of Medical Sciences, Port Harcourt, Rivers State-5200272, NIGERIA.

Phone: +234-0-8038046678

Email: wadioniaduema@gmail.com History

- Submission Date: 10-06-2019

- Review completed: 09-07-2019;

- Accepted Date: 23-07-2019.

DOI : 10.5530/ijcep.2019.6.2.17

\section{Copyright}

(C) 2019 Phcog.Net. This is an openaccess article distributed under the terms of the Creative Commons Attribution 4.0 International license.

\begin{abstract}
Background and Aim: The use of Mucuna flagellipes in recent time has been on the increase as a result of its speculated therapeutic effect mostly on the protein level of the body. And owing to the fact that there are no detailed reports on Mucuna flagellipes on its effect on neurobehavioral parameters, this work is therefore intended to investigate the possible effects of this herb on the exploratory behavior and body weight in Swiss white mice. Methods: Twenty (20) mice of mixed gender were randomly divided in to two groups of ten mice each. Group 1 served as the control, while group 2 received the Mucuna flagellipes diet. The feeding lasted for 31 days. The open field maze task was used to assess exploratory behavior. All mice were allowed free access to clean drinking water. Daily food intake, water intake and body weight change were measured. Results: The results showed that the Mucuna flagellipes diet fed mice had significantly increased $(p<0.01 ; p<0.05)$ line crossings, close arm duration and Stretch Attend Posture (SAP) compared to control. There was an increase in food intake and water intake $(p<0.001$ and $p<0.01)$ compared to control. However, the body weight change was statistically higher but not significant when compared to the control group. Conclusion: Therefore, consumption of Mucuna flagellipes improves exploratory behavior and body weight in mice. These may be has a result of an unknown phytochemical compound present in Mucuna flagellipes.

Key words: Mucuna flagellipes, Exploration, Body weight, Open field maze, Mice.
\end{abstract}

\section{INTRODUCTION}

The system of use of plants for food and drug dates back to the early man on earth. ${ }^{[1]}$ The use of natural products with therapeutic properties for chronic and acute diseases is as ancient as human civilization ${ }^{[2,3]}$ and, for a long time, mineral, plant and animal products were the main sources of drugs. ${ }^{[4]}$

Mucuna flagellipes which is commonly called cow itch and locally called Ibie, There are abundance of macro elements like calcium, magnesium and iron. ${ }^{[5,6]}$ The pod hairs have been used in India to treat snakebite ${ }^{[7,8]}$ while in West Africa; it is the stem that is used for treating of snakebite. ${ }^{[9]}$ Their stems have been reported to also improve sexual potency. ${ }^{[10,8]}$ Its pods have also been used to deworm patients. ${ }^{[1]}$ The use of Mucuna flagellipes in recent time has been on the increase as a result of its speculated therapeutic effect mostly on the protein level of the body ${ }^{[12]}$ And owing to the fact that there are no detailed reports on Mucuna flagellipes on its effect on neurobehavioral parameters, this work is therefore intended to investigate the possible effects of this herb on the exploratory behavior of Swiss white mice. The findings on the Swiss white mice can be extrapolated to humans with a fair measure of accuracy. Also, Based on the established fact that the demand of Mucuna is on the increase in the international market, its therapeutic significance elevated and the demand for enhancing neuro-cognitive performance are on the increase which can be seen in the rate at which students consume memory enhancing drugs like Nicotine, Caffeine and Amphetamine. Therefore this study is timely and justifiable as it will not only separate myth from fact alone, but also increase the demand for this plant, for the treatment and management of exploratory disorders.

\section{METHODS}

\section{Preparation and storage of experimental diet}

Dried leaves of Mucuna flagellipes was obtained from a local market in Umuahia, Abia State, Nigeria and pulverized with manual blender to obtain a fine powder. The powder was then kept in a dry and airtight container from which the Mucuna flagellipes were prepared. $30 \%$ of the Mucuna flagellipes diet was prepared by mixing $3 \mathrm{~g}$ of Mucuna flagellipes and $7 \mathrm{~g}$ of the rat fed. Approval for the use of the leave was authenticated in the Herbarium unit of the Department of Biological Sciences, Faculty of life Sciences, Abia State, Nigeria.

Cite this article: Aduema W, Amah AK, Akunneh-Wariso C. Improved Exploratory Behaviour and Body Weight in Mice Following Chronic Diet Consumption of Mucuna flagellipes. Int J Clin Exp Physiol. 2019;6(2):66-70. 


\section{Experimental Animals}

Experimental animals(mice) weighing between 20-21g were obtained from the animal house of the Department of Human Physiology, Faculty of Medicine, Abia State University and housed in a new wired cage in the same animal house were the mice acclimatized for two weeks. Prior to the commencement of the experiments. The mice were housed under standard laboratory condition, light and dark cycles of $12 \mathrm{hr}$ and were provided standard rodent pellet diet and water ad libitum. The mice were categorized into control and treated groups. The treated group was administered, in addition to feed and water for a period of four weeks.

\section{Experimental Design}

Twenty mice were assigned into two groups of ten mice per group. Group 1 served as the control, while the second group which is group 2 received the Mucuna flagellipes diet. The animals were placed on their respective diets for 31 days with their body weight assessed every 3 days. Approval of the animal was obtained from the college Ethical committee of the Faculty of Basic Medical Sciences, Abia State University, Uturu. In accordance with the accepted principles for laboratory animal use and care.

\section{Assessment of exploratory behavior}

The Open Field (OF) test, which provides simultaneous measures of locomotion, exploration and anxiety, ${ }^{[13]}$ was used for this study. The open field apparatus is constructed from white plywood with a $72 \times 72 \mathrm{~cm}$ floor and $36 \mathrm{~cm}$ walls. One of the walls is made of clear Plexiglas, so that mice could be visible in the apparatus. Blue lines are drawn on the floor with a marker and are visible through the clear Plexiglas floor. The lines divide the floor into sixteen $18 \times 18 \mathrm{~cm}$ squares. A central square $(18 \mathrm{~cm} \times 18 \mathrm{~cm})$ is drawn in the middle of the open field. ${ }^{[14]}$ The central square has sufficient space surrounding it to give meaning to the central location as being distinct from the outer locations. ${ }^{[15]}$

\section{The open field apparatus procedure}

Mice were carried to the test room in their home cages and tested one at a time for 5 min each. Each mouse was scooped up in a small plastic container from their home cage and placed at the centre square of the open field, then allowed to explore the apparatus for $5 \mathrm{~min}$. After the 5 min test, each of the mice was scooped up from the open field with the plastic container and returned to their home cages. The number of urinations and defecations for each mouse was counted and recorded

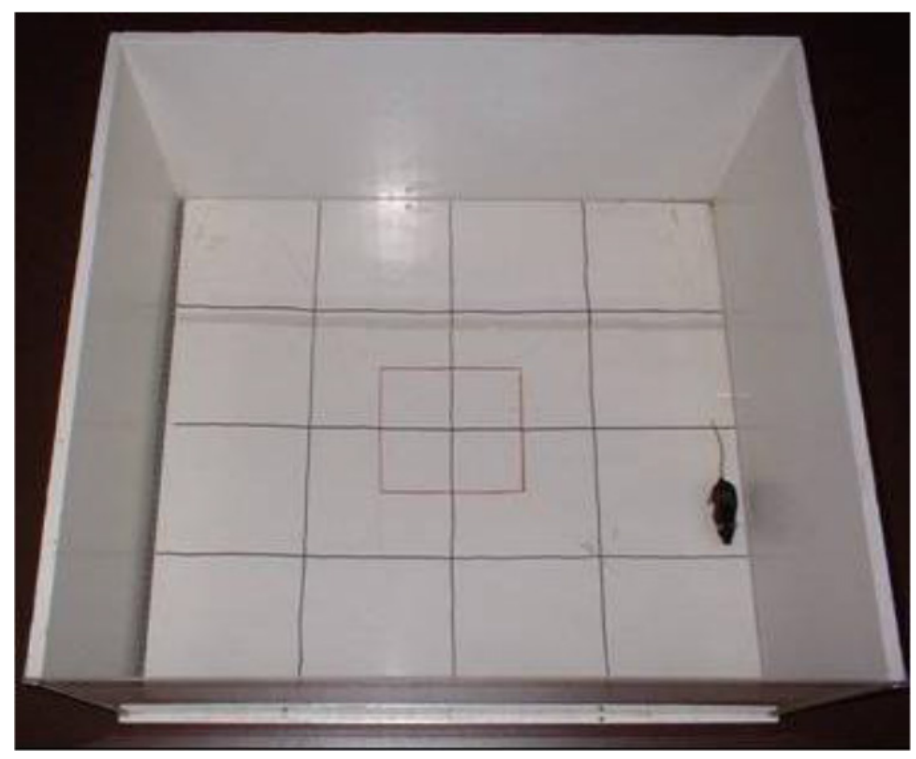

before the open field is cleaned with 70\% ethyl alcohol and permitted to dry between trials. This was to eliminate olfactory stimuli.

The behaviors scored, ${ }^{[14]}$ included:

1. Line Crossing: frequency with which the mice crossed one of the grid lines with all four paws.

2. Centre Square Entries: frequency with which the mice crossed one of the red lines with all four paws into the central square.

3. Centre Square Duration: amount of time the mice spent in the central square.

4. Stretch Attend Postures: Frequency with which the animal demonstrated forward elongation of the head and shoulders.

\section{Statistical analysis}

All data obtained were analyzed by one-way analysis of variance followed by post hoc student's $t$-test using the SPSS computer programme. Results are presented as mean \pm SEM and $p$ value less than 0.05 was considered statistically significant.

\section{RESULTS}

\section{Effect of Mucuna flagellipes on exploratory behavior in}

mice

\section{Line crossing}

Line crossing is a form of exploratory behaviour. In the 30\% w/w Mucuna flagellipes diet fed mice, the number of line crosses was 38.80 $\pm 4.98 / 5$ min, which was significantly higher $(p<0.01)$ compared to control which was 19.62/5 mins (Figure 1).

\section{Rearing frequency}

The frequency of rearing in the $30 \% \mathrm{w} / \mathrm{w}$ Mucuna flagellipes diet group was $34.6 \pm 2.70 / 5$ mins and it was significantly higher $(p<0.01)$ compared to control which was $7.55 \pm 3.00 / 5 \mathrm{~min}$. (Figure 2)

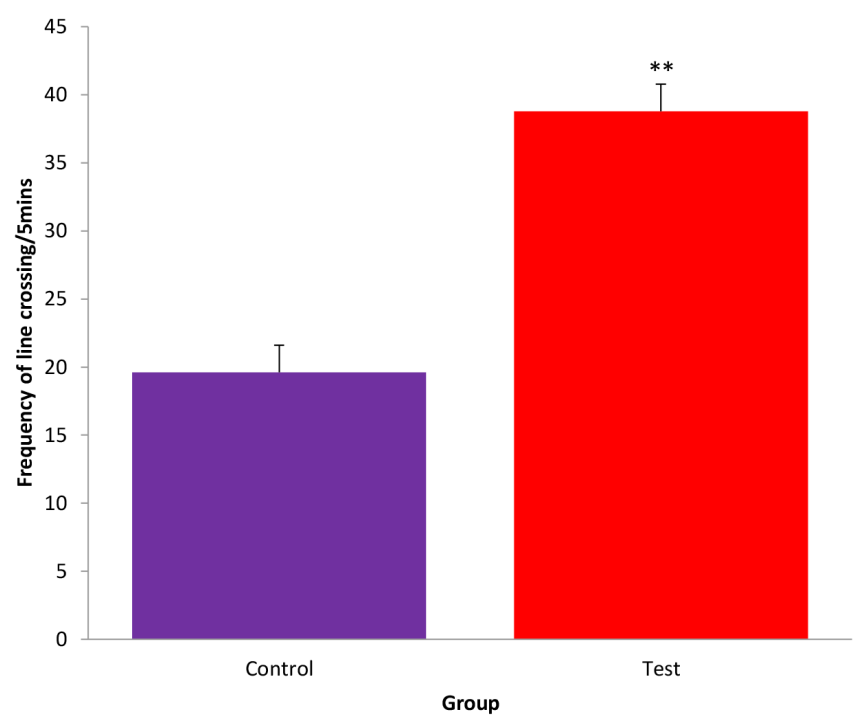

Figure 1: Effect of Mucana flagellipes on line crossing in the open field maze among the experimental groups.

**-Significant at $p<0.01$ compared to control. 


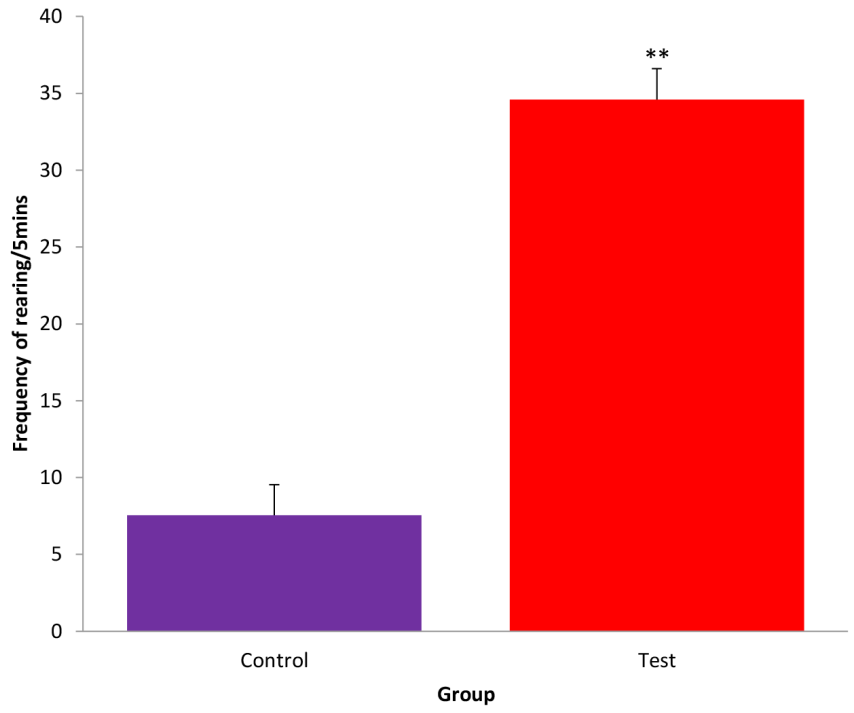

Figure 2: Effect of Mucuna flagellipes on rearing in the open field maze among the experimental groups.

**-Significant at $p<0.01$ compared to control.

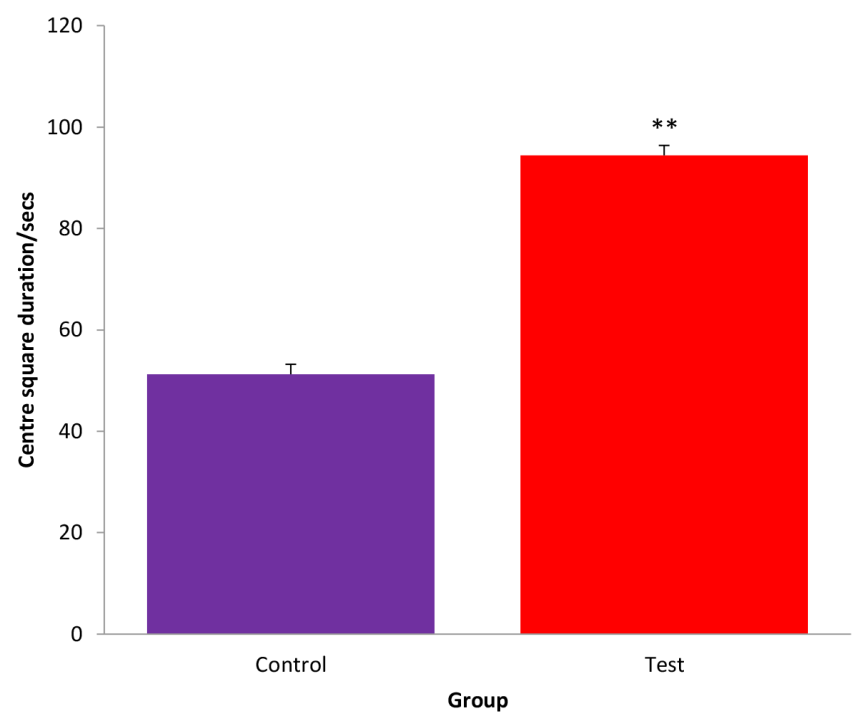

Figure 3: Effect of Mucuna flagellipes on centre square duration in the open field maze among the experimental groups.

**-Significant at $p<0.01$ compared to control.

\section{Centre square duration}

The duration of time spent in the centre square the 30\% w/w Mucuna flagellipes diet group was $94.40 \pm 3.75 / \mathrm{sec}$; which was significantly higher $(p<0.01)$ compared to control which was $51.22 \pm 3.46 / \mathrm{sec}$. Figure 3

\section{Stretch attend posture}

The SAP activity in the test mice fed with $20 \% \mathrm{w} / \mathrm{w}$ Mucuna flagellipes diet was $2.40 \pm 0.59 / 5 \mathrm{~min}$; which was significantly higher $(p<0.05)$ compared to the control group which was $0.80 \pm 0.36 / 5 \mathrm{~min}$. Figure 4 .

\section{Effect of Mucuna flagellipes on body weight in mice.}

The body weight change for the 30\% Mucuna flagellipes diet group was $26.4 \pm 1.07 \mathrm{~g}$, which was statistically higher but not significant, when compared to the control group which was $25.80 \pm 1.87 \mathrm{~g}$ (Figure 5).

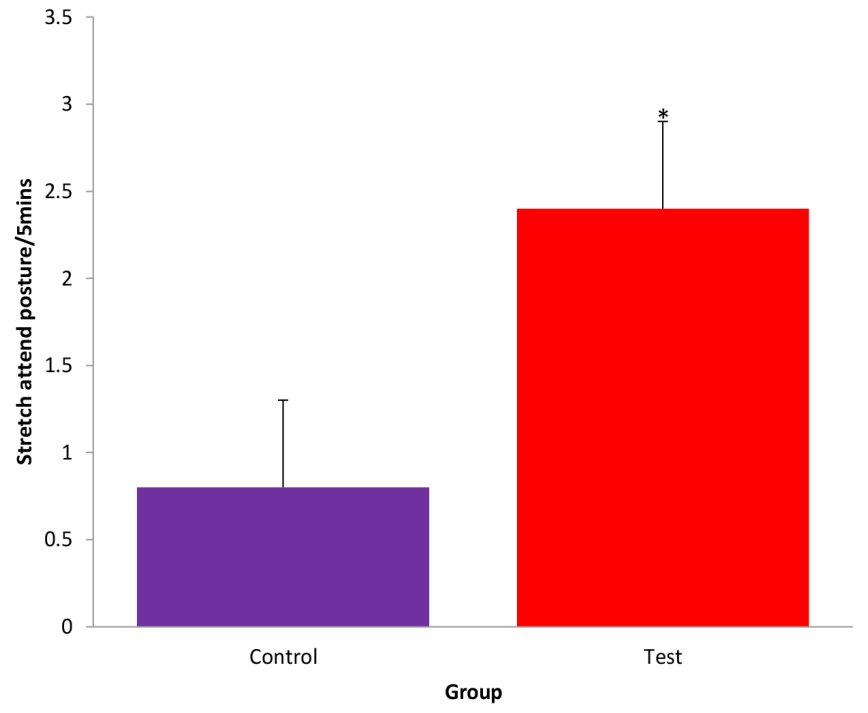

Figure 4: Effect of Mucuna flagellipes on stretch attend posture in the open field maze among the experimental groups.

*-Significant at $p<0.01$ compared to control.

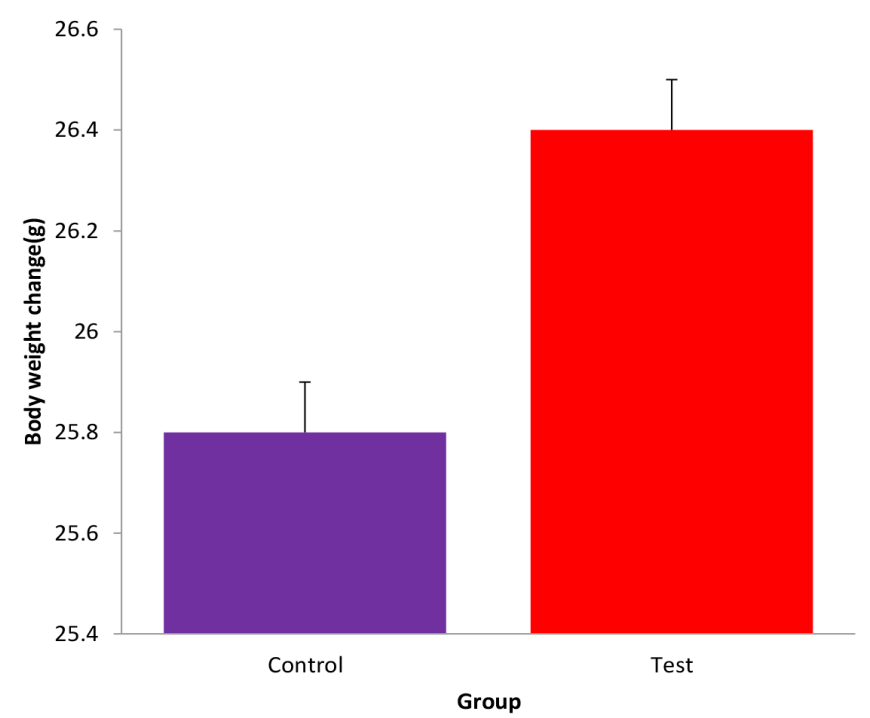

Figure 5: Effect of Mucuna flagellipes on body weight change among the experimental group.

NS- Not significantly different.

\section{Food intake}

The food intake for the 30\% Mucuna flagellipes diet group was $48.30 \pm 1.63 \mathrm{~g}$ which was significantly higher $(p<0.001)$ compared to the control group which was $30.50 \pm 11.86 \mathrm{~g}$. Figure 6 .

\section{Water intake}

The water intake in the $30 \%$ Mucuna flagellipes group was $46.00 \pm 11.69 \mathrm{mls}$ which was significantly higher $(p<0.01)$ compared to the control which was $27.70 \pm 16.43 \mathrm{mls}$ (Figure 7 ).

\section{DISCUSSION}

Centre square duration, walling, line crossing and rearing are usually used as measures of exploration and anxiety, the greater the frequency of these measures, the greater the exploratory behavior. In this study, the 


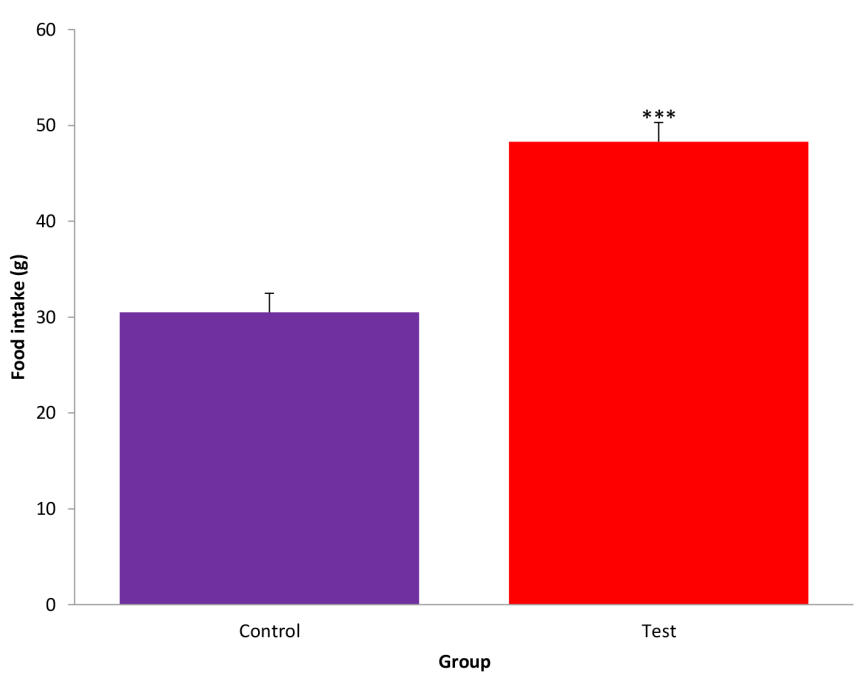

Figure 6: Effect of Mucuna flagellipes on food intake among the experimental group.

***-Significant at $p<0.001$ compared to control.

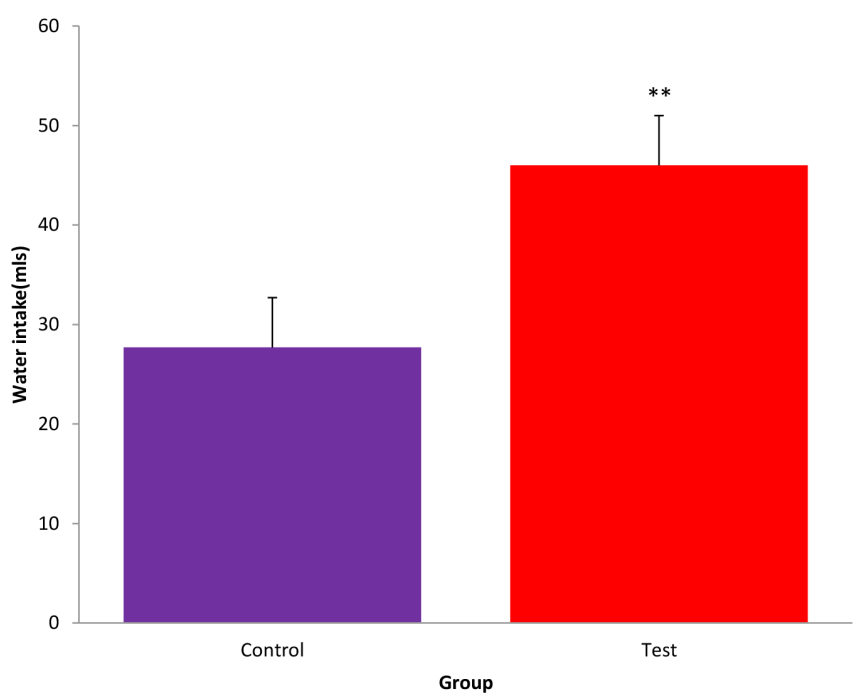

Figure 7: Effect of Mucuna flagellipes on water intake among the experimental groups.

**-Significant at $p<0.01$ compared to control.

$30 \%$ of Mucuna flagellipes diet group had a higher exploratory activity compared to the control as seen in the line crosses, rearing and centre square duration. The centre square duration are measures of exploratory behavior and anxiety, with higher frequency of these activities, indicating higher exploratory behavior and lower anxiety level. ${ }^{[13]}$ In this study, the $30 \%$ Mucuna flagellipes diet group had higher exploratory behavior as when compared to the control group. Exploration as well as locomotion activation results from brain activation which in turn manifest as excitation of the central neurons and eventually leads to an increase in cerebral metabolism. It has been reported that exploratory activation that occur naturally, such as (rearing, grooming, etc) and inhibition like rest and sleep may differ in its underlying mechanisms for similar behaviors induced by drugs. ${ }^{[16]}$ Pharmacological increase in dopamine either directly or indirectly by dopamine agonists result in higher exploratory/locomotor activity. ${ }^{[17]}$ Therefore, increased dopamine which may be a reason for brain hyperthermia has been known to correlate with increased exploration. ${ }^{[18-20]}$

The mean daily food intake for the Mucuna flagelipes diet group was significantly higher compared to control. Food and water intake is controlled by the lateral hypothalamic nucleus and the ventromedial hypothalamic nucleus. ${ }^{[21]}$ The lateral hypothalamic nucleus is the hunger centre and so, when stimulated the animal eats and drinks voraciously. On the other hand, ventromedial hypothalamic nucleus is the satiety centre and so, when stimulated the animal stops feeding. It is possible therefore, that the 30\% Mucuna flagellipes diet may have a stimulatory effect on the lateral hypothalamic nucleus thus causing hunger, thereby increasing food intake. Similarly, the mean water intake was also significantly different between the test groups and the control group. Water intake is controlled by the Osmoreceptors or 'thirst' receptors in the hypothalamus. ${ }^{[22]}$ It is likely that certain unknown chemical constituents in Mucuna flagellipes may be responsible for the stimulation of the thirst centre thus increasing thirst. The mean body weight change was statistically higher in the Mucuna flagellipes diet group but not significant when compared with the control. This may be attributed to the increase in food and water intake observed in the mice fed with Mucuna flagellipes diet.

\section{CONCLUSION}

Our study revealed that Mucuna flagellipes improves exploration and body weight in mice. These effects may be due to the total constituent of Mucuna flagellipes.

\section{ACKNOWLEDGEMENT}

We acknowledge Mr. Uchenna Azunna and Mr. Nomso for their priceless support.

\section{CONFLICT OF INTEREST}

The authors declare no conflict of interest.

\section{ABBREVIATIONS}

SAP: Stretch attend posture; OP: Open field; SEM: Standard error of mean.

\section{REFERENCES}

1. Miller LG. Herbal medicine: Selected or potentiating herb interaction. Archives of Internal Medicine. 1998;158:2200-11.

2. Borris RP. Natural product research. J Ethnopharmacol. 1996;51(1-3):29-38.

3. Dureja H, Kaushik D, Kumar V. Developmentats in nutraceuticals. Indian J Pharmacol. 2003;35:363-72

4. Depasquale A. Pharmacognosy: The oldest modern Science. J Ethnopharmacol 1984;11(1):1-16.

5. Rajaman N, Jonardhaman K. The botanical composition and nutritional potential of the tribal pulse, Mucuna gigants (wild) DC plant food for human. Nutrition. $1991 ; 41(1): 45-51$.

6. Sexena P. Records of Aphis craccirora Koch (He niptera aphidae) on medicinal crop. Mucuna puriens L. Chh. Athisgarh (India). Insect Environment. 2001;7(I):24-5

7. Weiner BA. Cognitive (attribution)-emotion-action model of motivation behavior: Analysis of judgments of help-giving. Journal of Personality and Social Psychology. 1984;32(2):186-200

8. Siddhuragu PK, Vijiayakumari JK. Chemical composition and protein quality of little-known legumes velvet Bean (Mucuna pruriens (L.) DC.). Journal of Agricultural and Food Chemistry. 1996;44(9):2636-41.

9. Houghton J. Flora of West Africa. Longman. 1994;1:10-5

10. Thompson W. Medicine from the earl company Maiden head, United Kingdom McGraw-Hill book. 1978.

11. Faridah H, DerMaesenh JIV. Prosea handbooks No 1, auxiliary plants pros seal Bogor, Wagering. Netherlands. 1996;16-7.

12. Farooqui IS, Jebb SA, Landmack $E$, Cheetham $C H$, Prentice $A M$, Hughes IA et al. Effect of recombinant Leptin therapy in child with congenital Leptin deficiency. Engl Med.1999;341(12):879-84. 
13. Walsh RN, Cummins RA. The open field test: A critical review. Psychological Bulletin. 1976;83(3):482-504.

14. Brown RE, Corey SC, Moore AK. Differences in measures of exploration and fear in $\mathrm{MHC}$-congenic $\mathrm{C} 57 \mathrm{BL} / 6 \mathrm{~J}$ and $\mathrm{B} 6-\mathrm{H}-2 \mathrm{~K}$ mice. Behavior Genetics. 1999;29(4):263-71.

15. Carrey NR, Mcfayden MP, Brown RE. Effects of chronic methylphenidate administration on locomotor and exploratory behaviour of Prepubertal mice. Journal of Child and Adolescent Psychopharmacology. 2000;10(4):277-86.

16. Brown $\mathrm{PL}$, Bae $\mathrm{D}$, Kiyatkin EA. Relationship between locomotor activation and alteration Brain temperature during selective blockade and stimulation of dopamine transmission. Neuroscience. 2007;145(1):335-45.
17. Wise RA, Bozarth MA. A Psychomotor stimulant theory of addiction. Psychological Review. 1987;94(4):469-92.

18. Brown PL, Kiyathin EA. Brain hyperthermia is induced by methamphetamine and exacerbated by social interaction. J Neurosci. 2003;23(9):3924-9.

19. Brown PL, Wise RA, Kiyathin EA. Brain hyperthermia induced by MDMA (ecstacy): Modulation by environmental conditions. Eur J Neurosci. 2004;20(1):51-8.

20. Kiyathin EA. Brain hyperthermia as physiological and pathological phenomena. Brain Res Rev. 2005;50(1):27-56.

21. Osim EE. Neurophysiology Calabar. University of Calabar Press. 2008;24-7.

22. Guyton AC, Hall JE. The nervous system. Textbook of Medical Physiology. London: Saunders Company. 2006;675-701.

Cite this article: Aduema W, Amah AK, Akunneh-Wariso C. Improved Exploratory Behaviour and Body Weight in Mice Following Chronic Diet Consumption of Mucuna flagellipes. Int J Clin Exp Physiol. 2019;6(2):66-70. 